\title{
Female adnexal tumour of probable Wolffian origin
}

\author{
Y. SIVATHONDAN, R. SALM ${ }^{1}$, P. E. HUGHESDON, AND J. M. FACCINI ${ }^{2}$ \\ From the Departments of Morbid Anatomy of University College Hospital Medical School, London and \\ the Royal Cornwall Hospital (Treliske), Truro, Cornwall, UK
}

SUMmaRY Two further cases of 'female adnexal tumour of probable Wolffian origin' a re described Both were retroperitoneal and presented a unique histology of uniformly close-packed gland spaces. solid islands, cords, and diffuse areas. A small hamartoma in a female fetus, part of which resembled the tumours, was traced to an area of near apposition with some paroophoron canals, providing further evidence of a Wolffian origin. The literature of this and some other putative Wolffian tumours is briefly reviewed, and the relation to rete adenomas is discussed.

True tumours of the broad ligament are uncommon and many of them resemble primary tumours of the ovary and uterus (Gardner et al., 1957). Recently, Karaminejad and Scully (1973) described nine cases of a rare broad ligament adenoma for which they proposed an origin from the Wolffian (mesonephric) duct and tubules, on account of its site and histological distinctiveness, even though it bore no resemblance to any known mesonephric derivative. The chequered history of the term 'mesonephroma' led them to prefer the title 'female adnexal tumor of probable Wolffian origin'. The present article describes two more such cases and supplies further evidence from fetal material to support a mesonephric origin.

\section{Case reports}

\section{CASE 1}

Mrs F. aged 52, para 0, one year past the menopause, was admitted to hospital with frequency of micturition of some months' duration. Her past history was unremarkable save for mild hypertension, and she had no signs of virilism. A mass was felt rising out of the pelvis, and operation (10 December, 1957; Mr Herbert Reiss) disclosed a few small uterine

1Present address: Department of Histopathology, Royal Postgraduate Medical School, Hammersmith Hospital, Ducane Road, London W12

2Present address: Director of Pathology, Centre de Recherche Laboratoires, Pfizer, Amboise, France

Received for publication 4 December 1978 fibroids and a grapefruit-sized tumour extending from the lateral pole of the right ovary between the layers of the broad ligament; this was removed together with the uterus and adnexa. The nature of the tumour was unclear until after publication of the article cited when Dr Scully, to whom sections had been sent, kindly confirmed the diagnosis. At the time diagnoses of 'arrhenoblastoma of intermediate type' and 'adenomatous granulosa cell tumour' were entertained but considered to be unsatisfactory. The patient was given a course of postoperative radiotherapy $(3000 \mathrm{r}$ to the pelvis and $2600 \mathrm{r}$ to the abdomen) and in 1976 was free from recurrence and well apart from intercurrent illness (ischaemic heart disease).

\section{CASE 2}

Mrs R. aged 62, para 2, 10 years past the menopause was admitted to hospital with a history of intermittent postmenopausal bleeding. She had had no relevant past illnesses. Two previous curettages had shown retrogressed cystic endometrial hyperplasia with polypi, and, as the uterus was enlarged, hysterectomy was recommended. Operation (10 June 1975; Mr Brian Cox) disclosed a uterus enlarged by fibroids and fixed by adhesions, due possibly to diverticulitis, and a retroperitoneal mass adjacent to the left ovary. Panhysterectomy was performed, with dissection of the mass by medial reflection of the colon, together with removal of a small calcified fibroid behind the bladder. The nature of the retroperitoneal tumour was unclear, diagnoses of 'malignant synovioma' and 'metastatic adenocarcinoma' being entertained but considered to be 616 
unsatisfactory; it was finally identified by comparison with that of case 1 . The patient was well and free from recurrence in May 1977.

\section{Macroscopic pathology}

CASE 1

The uterus, $9 \times 9 \times 4 \mathrm{~cm}$, contained a few fibroids, the largest $3 \mathrm{~cm}$ in diameter. The tubes were unremarkable, and the left ovary, $3 \times 1.5 \times 0.8 \mathrm{~cm}$, was small and firm. The right ovary spread out at its lateral pole to form a surface plaque on an irregularly ovoid tumour, $15 \times 12 \times 8 \mathrm{~cm}$, which elsewhere had a thin capsule and on section was soft, solid, lobulated, and butter-yellow.

\section{CASE 2}

The uterus, $12 \times 6 \times 6 \mathrm{~cm}$, showed multiple fibroids, the largest $4 \mathrm{~cm}$ in diameter, an endometrial polypus, and a cervical mucous polypus. The ovaries were slightly enlarged, firm and yellow. The tumour, $10 \times$ $8 \times 5.5 \mathrm{~cm}$, was encapsulated, firm and rubbery, and pale brown on section, with a few small cavities.

\section{Microscopic pathology}

Both tumours resembled those described by Karaminejad and Scully (1973) in consisting of winding and branching tubules of varied size (Fig. 1), mostly small; solid islands and cords, also variable; and areas of diffuse growth, closely packed into a massive, non-lobular architecture with scanty, often barely perceptible stroma. There were, however, some differences between the two cases.

In case 1 the cells were conspicuously dark, with scanty cytoplasm and nondescript nuclei, mostly ovoid or distorted into an oblong or pear shape (Fig. 2). Those lining the tubules were cubical, sometimes flattened in dilated forms, and pseudostratified in smaller ones. Many larger tubules had a leafy, indented outline, while the smaller were mostly round, ovoid, or reniform, recalling a tubular adenoma. Cords varied from 1 to 4 cells in thickness; most were two-celled with their cells orientated along the line of the cords or obliquely to them rather than transversely. Diffuse areas acquired a sarcomatoid appearance (Fig. 3) with interlacing and radiate

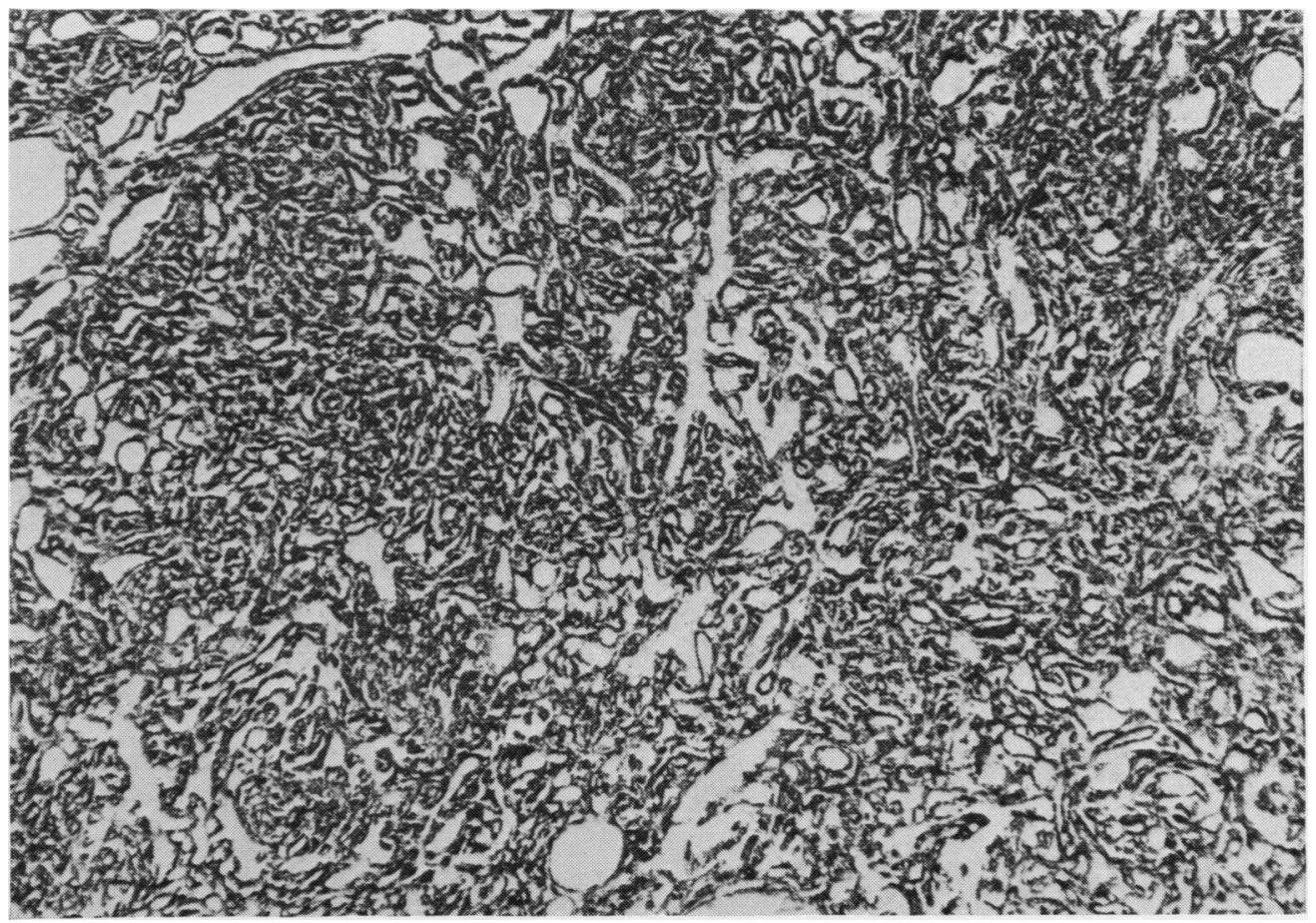

Fig. 1 Case 1. Low-power view showing massive, close-packed arrangement of interwoven tubules with occasional dilatation and no lobular subdivision. Haematoxylin and eosin $\times 50$ 


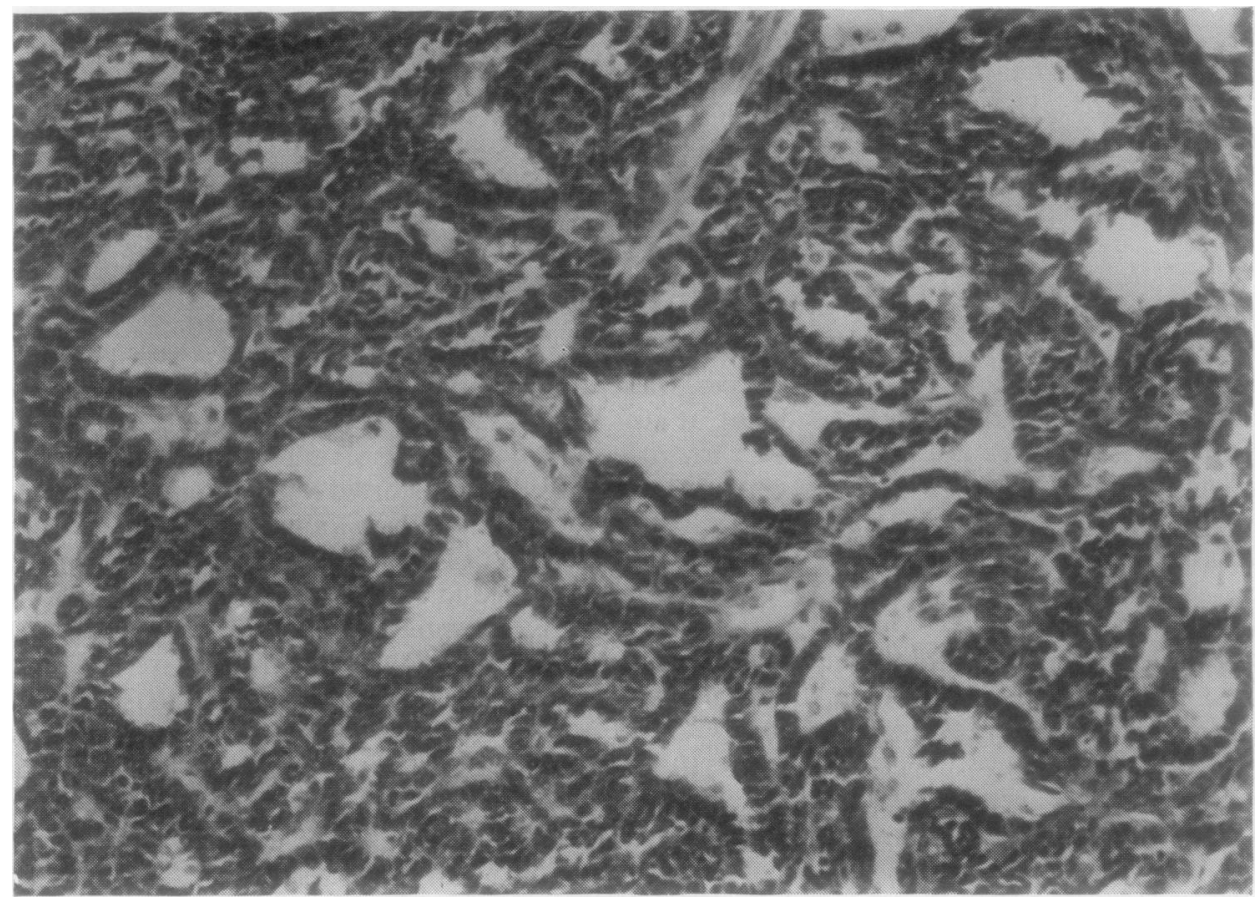

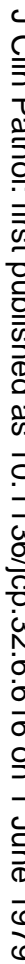

Fig. 2 Case 1. The same section as in Fig. 1 at higher power showing packed variegated tubules with dark cubical epithelium. $H$ and $E \times 125$

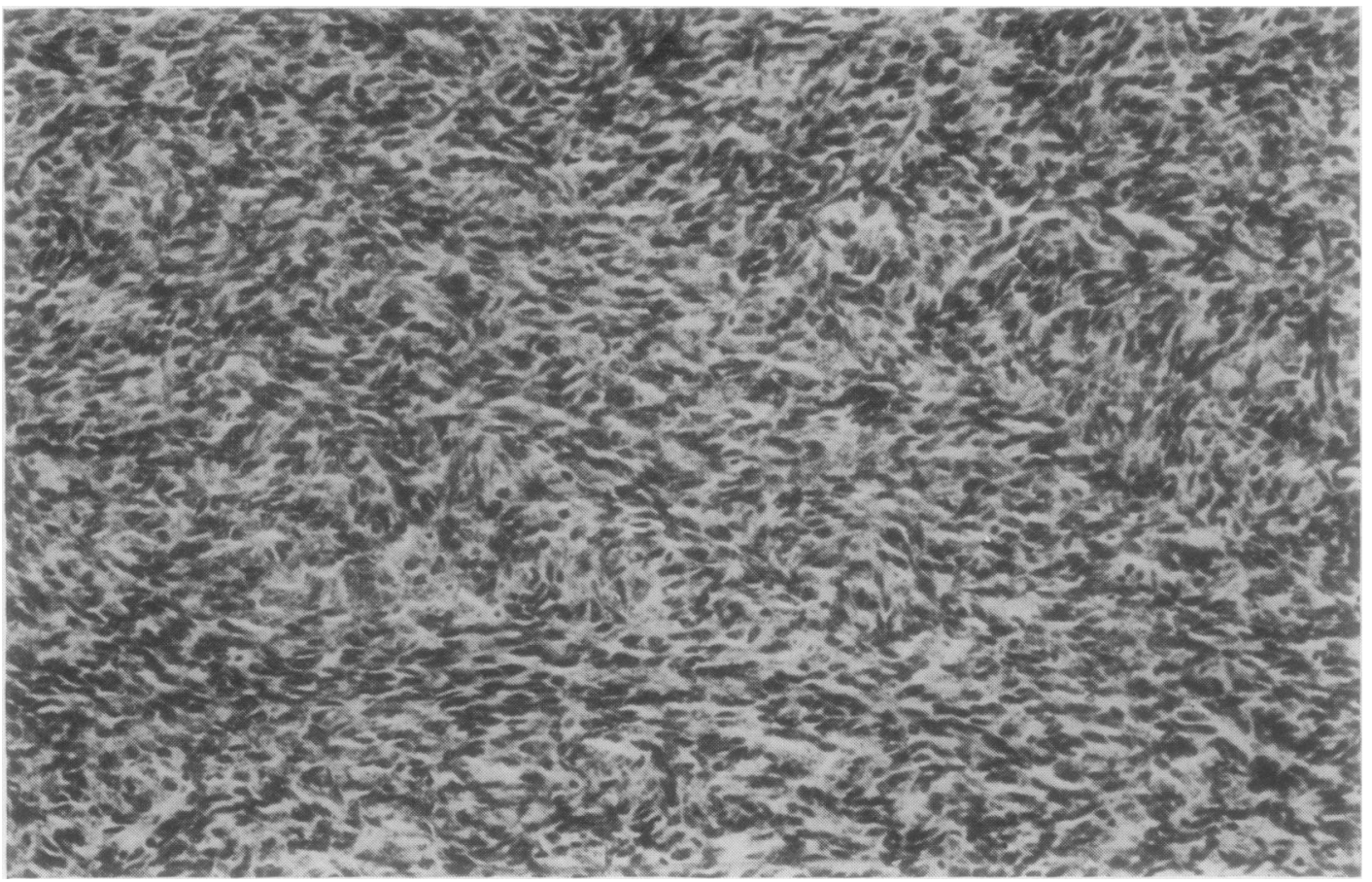

Fig. 3 Case 1. Diffuse sarcomatoid area with ill-formed acini and cords on the left. $H$ and $E \times 125$ 


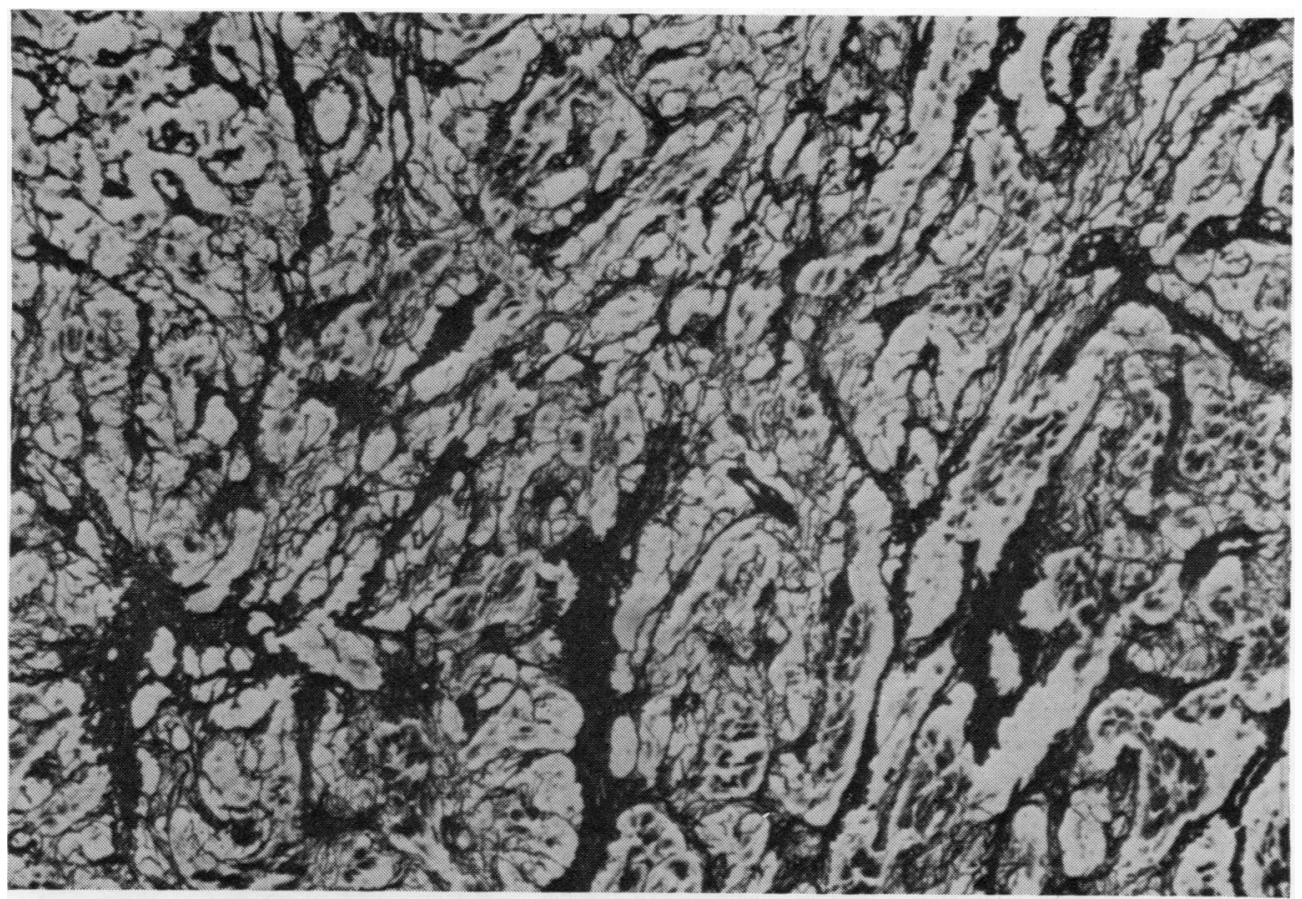

Fig. 4 Case 1. Reticulum impregnation showing mainly peri-insular, occasionally pericellular, arrangements. Gordon and Sweet $\times 125$

patterns of fusiform cells and occasional cord-like condensations. The reticulin pattern was mostly peri-insular, bringing out the essentially alveolar pattern of the tumour even in diffuse areas, but occasionally in the latter it was pericellular (Fig. 4). No elastic tissue was found and no smooth muscle was certainly identifiable by PTAH staining. Some lumina, especially in dilated tubules, contained a few exfoliated cells and a little PAS-positive material. Mitoses were present but scanty. The left ovary was atrophic, and the endometrium showed an active cystic hyperplasia.

In case 2 the cells had more cytoplasm, which was pale or weakly eosinophilic, and sharply defined ovoid vesicular nuclei. Those lining the tubules were mostly columnar, with pseudostratified nuclei; a few gave the impression of ciliation. Lumina were generally empty but occasionally contained a little PASpositive material. There were many clusters of dilated tubules with low or flat epithelium, producing a sieve-like, angiomatoid appearance (Fig. 5). In the solid cords, the cells and nuclei remained epithelioid and similar, with random orientation. Diffuse areas were inconspicuous and consisted chiefly of closely packed cords, but a mesenchyme-like appearance was assumed in a few subcapsular areas. Mitoses were absent. The ovaries in case 2 showed marked stromal hyperplasia with foci of thecosis, and the endometrium cystic hyperplasia, probably in early retrogression but with active areas, a large endometrial polypus, and occasional mitoses.

Both tumours showed occasional papillary protrusions into dilated tubules, not convincingly glomeruloid (Fig. 6), and both showed a PASpositive basement membrane around tubules and cords (Fig. 7), reinforcing the alveolar impression of the reticulum. Both showed a few, small, irregular areas of poorly cellular connective tissue, which nowhere extended to divide the massive continuum into lobules, and both showed at low power an interlacing, rather divergent growth habit: a capsule of poorly cellular connective tissue in which narrow cords of tumour cells extended in places to the outer surface.

The ovaries, broad ligaments, and tubes of a 26-week-old stillborn female infant (case 3) were reduced to interrupted serial sections. At one point in the mesosalpinx was a microscopic hamartoma, about $0.5 \mathrm{~mm}$ maximum diameter, consisting of an epidermoid formation continuous with a cluster of small tubules and solid islands (Fig. 8), recalling those in the case 1 tumour; the resemblance was 


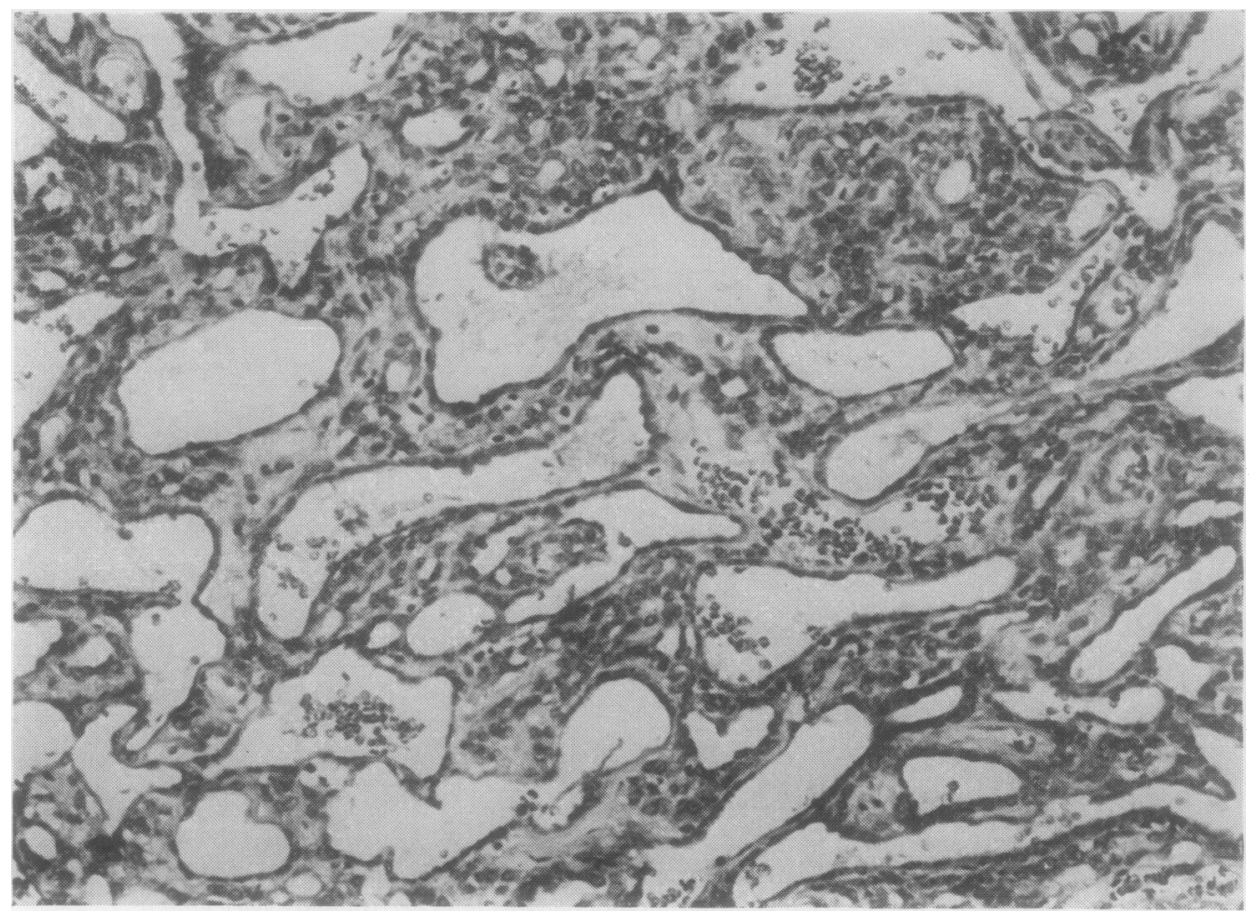

Fig. 5 Case 2. Mesothelioid area showing tubules lined by low or flat epithelium with some intervening cords. $H$ and $E \times 125$

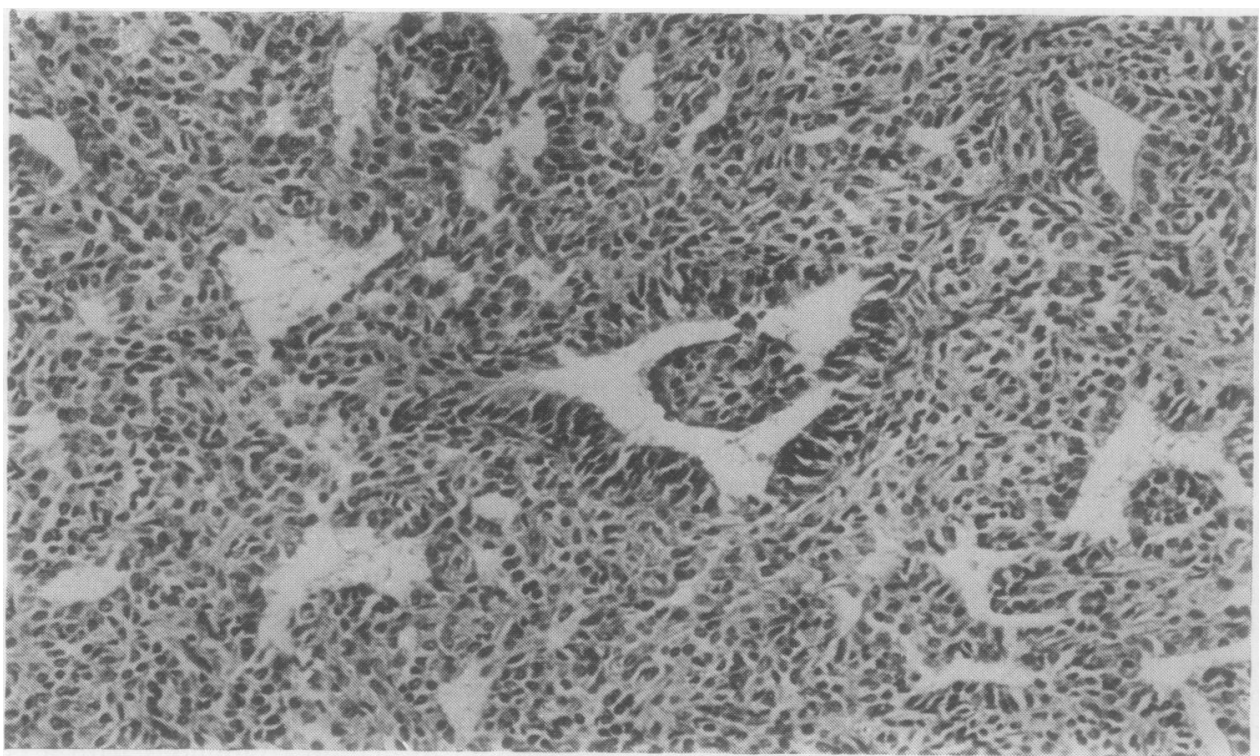

Fig. 6 Case 2. Close-packed, pale, solid islands and varied tubules with pseudostratified epithelium and a pseudoglomerular papillation. $H$ and $E \times 125$ 


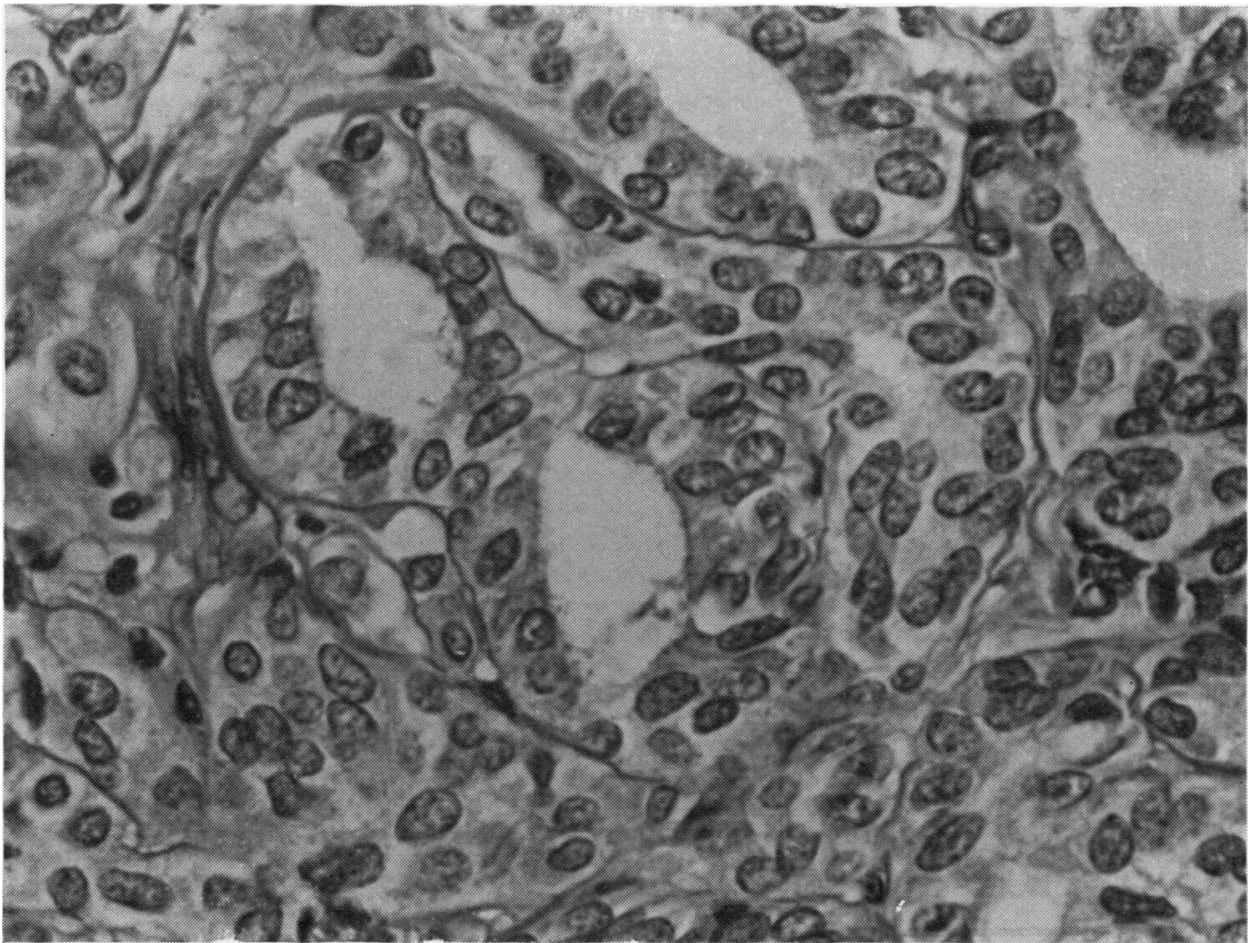

Fig. 7 Case 2. High-power view of glandular and insular area showing PAS-positive basement membrane. PAS $\times 500$

confirmed by Dr Scully. On tracing through adjacent sections, the tubules disappeared but the epidermoid formation near its deeper end came into close relation with a set of paraoophoron canals (Fig. 9). Continuity was not observed but may have been present in the discarded intermediate sections. The canals were in an area of broad ligament medial to and remote from the epoophoron, which was present elsewhere in the section close to the tube.

\section{Discussion}

The habit of ascribing a Wolffian origin to female pelvic pathology of uncertain nature probably began with von Recklinghausen's monograph (1896) referring adenomyomas to this source. Since then a Wolffian origin has been proposed for mucinous and other common epithelial tumours of the ovary (Corsy and Montpellier, 1927; Masson, 1922), Brenner tumours (Schiller, 1934), broad ligament cystomas (Gardner et al., 1948), adenomatoid tumours (Teilum, 1954), certain types of cervical papillomas (Janovski and Kasdon, 1963), and some cervical mixed mesodermal tumours (Marshall, 1959). None of these has distinctive histological features to attest such an origin.

In 1939, Schiller described under the title 'mesonephroma ovarii' 10 cases of an apparently distinctive ovarian tumour of adenopapillary and labyrinthic structure with prominent flat and hobnail epithelium. Five of these cases were under and five over 30 years of age. The former have since been categorised as germ-cell tumours reproducing extra-embryonic structures (Huntington and Bullock, 1970; Teilum, 1959), while the latter, after being assimilated to clear-cell carcinomas of the ovary and classed with comparable tumours of the broad ligament, cervix, and vagina (Novak et al., 1954; Teilum, 1954), retained for a time the title 'mesonephroid'. More recently, they have been related to the endometrioid tumours (Scully and Barlow, 1967; Czernobilsky et al., 1970), being probably a deciduoid variant, reproducing in different areas the Arias-Stella reaction and the flat, hobnail eosinophil and pale epithelia found in decidua. A like assessment as of local Müllerian origin has been made of the vaginal 


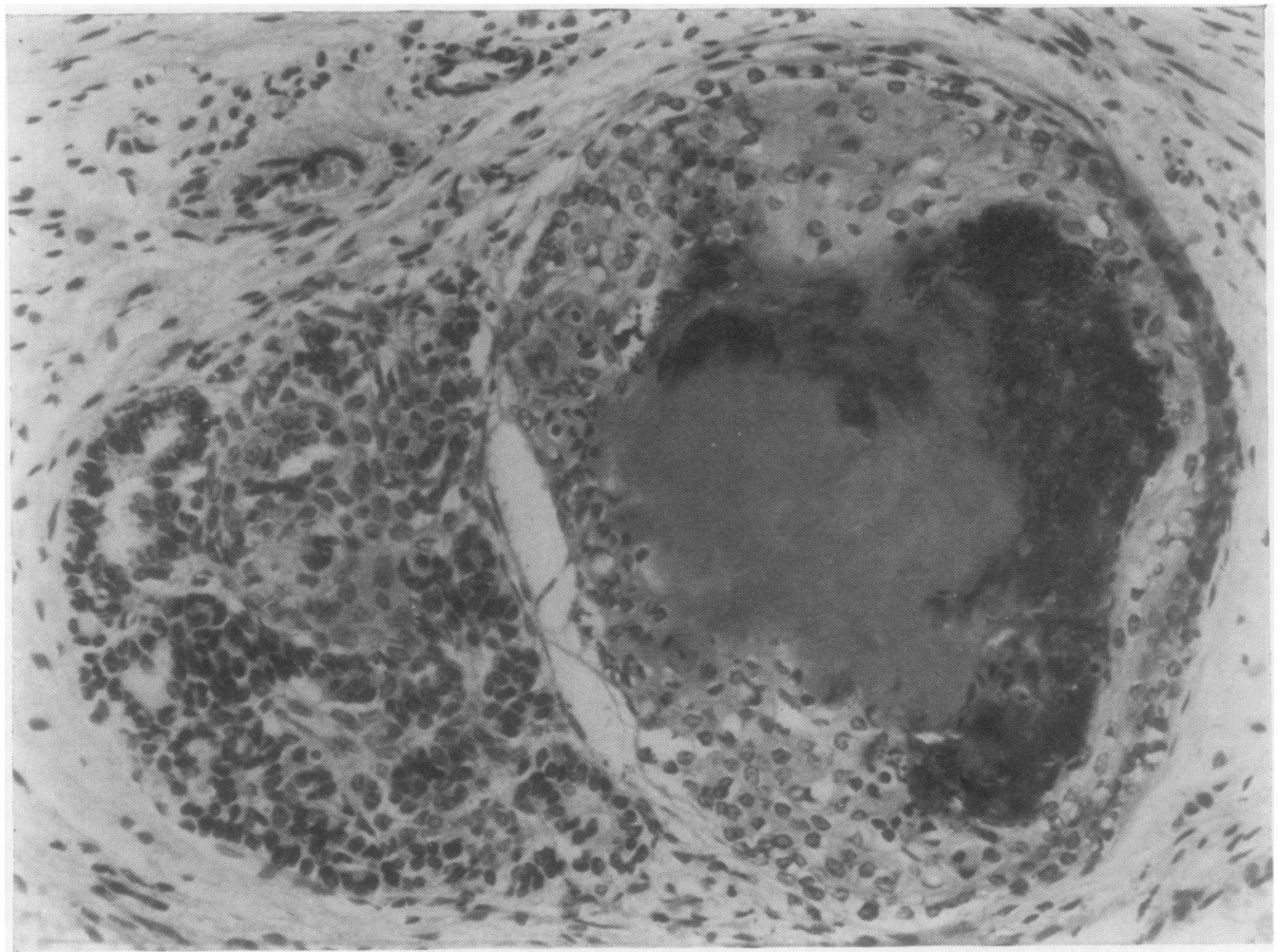

Fig. 8 Case 3. Microhamartoma showing epidermoid island and tumourlet of small tubules and islands. $H$ and $E \times 270$

tumours (Herbst and Scully, 1970) so that the category of 'mesonephroma' for most of these sites remains largely vacant.

Some of the cervical tumours have fared better. Most resemble those of the last category in appearance and assessment, but a few have shown among other morphological features clusters of closelying or apposed small acini, with or without solid islands and cords, recalling an appearance common in adenomatous hyperplasia of the ampulla of Gartner's duct (Meyer, 1900; Wolfe, 1940). Such tumours include those of Meyer (1907), Huffman (1948), probably case 5 of Novak et al. (1954), and McGee et al. (1962). These features have some analogy of structure with the broad-ligament tumours here described, but the resemblance is not close. Taken with varied other cases listed by Huffman (1948), the inconvenient possibility arises that true Wolffian tumours may be of variable appearance.

The characterisation of the present tumour as mesonephric depends on its site in the broad ligament where Wolffian remains are regularly found; on its distinctive histology, which resembles that of no established ovarian or other tumour; and on its prominent, PAS-positive basement membrane, which is a feature of the mesonephric duct and tubules (Gardner et al., 1948) and of some of their cervical tumours (Lamb et al., 1960; McGee et al., 1962). The histology has otherwise no close resemblance to Wolffian remains and their simpler pathology but has some to the tumourlet of case 3, attached to a tiny epidermoid formation, which was traced to contiguity with a mesonephric tubule. Epidermoid cysts of Gartner's duct in fetal and neonatal material were described by Meyer $(1902,1912)$, who considered that they later atrophied. We know of no published later case in the broad ligament, but a few have been described in the ovary and the testis (More, 1967).

Published reports of this tumour of certain identity include the original nine cases (Karaminejad and Scully, 1973), a single later one (Taxy and Battifora, 1976), and the two present cases. A conjectural case with a hint of the structure has been a retroperitoneal tumour of 'renal blastema'(Ackerman, 1954). Of the definite cases, that of Taxy and 


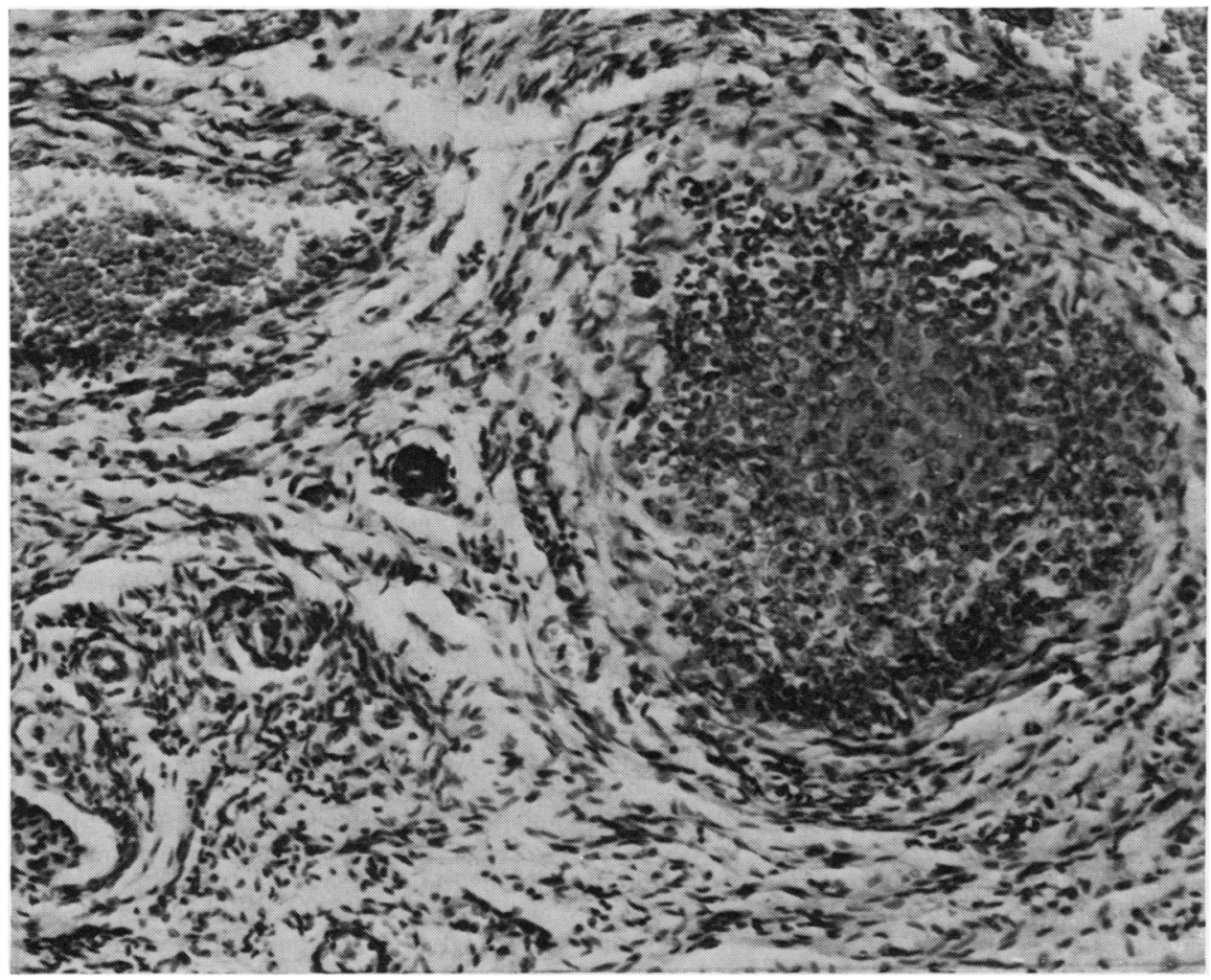

Fig. 9 Case 3. Deeper level of the tumour in Fig. 8 showing edge of epidermoid formation and, nearby, tiny paroophoron tubules. $H$ and $E \times 200$

Battifora recurred with hepatic metastases after six years; seven from the original series and the two present cases behaved benignly after follow-up ranging from 15 months to 19 years, but only two of these had been followed for six years or longer at the time of publication.

The main differential diagnoses are the four indicated in the text. Among these, the resemblance to arrhenoblastoma (androblastoma, Sertoli-Leydig cell tumour) is certainly the most striking. The main difference (in the absence of interstitial cells) is that arrhenoblastoma tends to be multi-insular or even lobulated, with cellular and differentiated zones separated by poorly cellular, featureless areas; while the present tumour (to judge by our cases) lacks this feature, being massive and continuous in architecture, with evidence of lobularity absent or barely discernible. It is possible, however, that the two tumours overlap. Both have a disposition to produce small tubules, solid islands, cords, and nondescript or diffuse areas; and both derive from or reproduce different parts of the male genital duct system, which changes from a Wolffian to a gonadal origin at the rete ovarii. The last forms within the gonadal perimeter in the embryo but is likely to receive a small contribution from the mesonephros during the proliferation which establishes continuity with its tubules. Reported small tumours of the rete ovarii include one of the present type (Greene and Dilts, 1965; Karaminejad and Scully, 1973), two of ambiguous claracter (Gardner et al., 1948; Greene and Dilts, 1965; Meyer, 1912; Meyer, 1931), and two of Sertoliform type with solid tubules having transversely elongated cells (Stange, 1956; Sternberg, 1963); we have seen two similar to the last. Further, some arrhenoblastomas develop a more massive and continuous non-insular pattern, and these, in our experience, tend to be oestrogenic rather than androgenic. It is of interest, therefore, that both our cases had endometrial evidence of present or recent oestrogenic stimulation, as did one case in the original series (Karaminejad and Scully, 1973), though clearly the chances that this was coincidental are high. 


\section{References}

Ackerman, L. V. (1954). Tumors of the retroperitoneum, mesentery and peritoneum. Atlas of Tumor Pathology, Section VI-fascicles 23 and 24, p. 65. Armed Forces Institute of Pathology, Washington.

Corsy, F., and Montpellier, J. (1927). Sur les évolutions cellulaires, le diagnostic histologique et les homologies des epithéliomes ovariens issus de vestiges wolffiens. Bulletin du Cancer, 16, 537-571.

Czernobilsky, B., Silverman, B. B., and Enterline, H. T. (1970). Clear-cell carcinoma of the ovary: a clinicopathologic analysis of pure and mixed forms and comparison with endometrioid carcinoma. Cancer, 25, 762-772.

Gardner, G. H., Greene, R. R., and Peckham, B. M. (1948). Normal and cystic structures of the broad ligament. American Journal of Obstetrics and Gynecology, 55, 917-939.

Gardner, G. H., Greene, R. R., and Peckham, B. (1957). Tumors of the broad ligament. American Journal of Obstetrics and Gynecology, 73, 536-555.

Greene, R. R., and Dilts, P. V., Jr. (1965). Adenoma of the rete body. American Journal of Obstetrics and Gynecology, 93, 886-888.

Herbst, A. L., and Scully, R. E. (1970). Adenocarcinoma of the vagina in adolescence: a report of 7 cases, including 6 clear-cell carcinomas (so-called mesonephromas). Cancer, 25, 745-757.

Huffman, J. W. (1948). Mesonephric remnants in the cervix. American Journal of Obstetrics and Gynecology, 56, 23-40.

Huntington, R. W., Jr., and Bullock, W. K. (1970). Yolk sac tumors of the ovary. Cancer, 25, 1357-1367.

Janovski, N. A., and Kasdon, E. J. (1963). Benign mesonephric papillary and polypoid tumors of the cervix in childhood. Journal of Pediatrics, 63, 211-216.

Karaminejad, M. H., and Scully, R. E. (1973). Female adnexal tumor of probable Wolffian origin. Cancer, 31, 671-677.

Lamb, E. J., Fucilla, I., and Greene, R. R. (1960). Basement membranes in the female genital tract. American Journal of Obstetrics and Gynecology, 79, 79-85.

McGee, C. T., Cromer, D. W., and Greene, R. R. (1962). Mesonephric carcinoma of the cervix: differentiation from endocervical adenocarcinoma. American Journal of Obstetrics and Gynecology, 84, 358-366.

Marshall, C. E. (1959). Mesonephroblastoma of the uterine cervix. British Journal of Surgery, 46, 649-650.

Masson, P. (1922). Essai sur les tumeurs non tératoïdes de l'ovaire. Gynécologie et Obstétrique, 6, 81-105.

Meyer, R. (1900). Ueber Drüsen, Cysten und Adenome im Myometrium bei Erwachsenen. Part 1. Zeitschrift für Geburtshülfe und Gynäkologie, 42, 526-546.

Meyer, R. (1902). Ueber Ektoderm- (Dermoid-) Cysten im Ligamentum latum, am Samenstrang und Neben- hoden bei Foetus und Neugeborenen. Virchows Archiv für pathologische Anatomie, 168, 250-264.

Meyer, R. (1907). Beitrag zur Kenntnis der Gartnerschen Ganges beim Menschen. Zeitschrift für Geburtshülfe und Gynäkologie, 59, 234-262.

Meyer, R. (1912). Zur Kenntnis der normalen und abnormen embryonalen Gewebseinschlüsse und ihre pathologischen Bedeutung. Zeitschrift für Geburtshülfe und Gynäkologie, 71, 221-320.

Meyer, R. (1931). The pathology of some special ovarian tumors and their relation to sex characteristics. American Journal of Obstetrics and Gynecology, 22, 697-713.

More, J. R. S. (1967). Epidermoid cyst of the ovary. Gynaecologia, 164, 240-248.

Novak, E., Woodruff, J. D., and Novak, E. R. (1954). Probable mesonephric origin of certain female genital tumors. American Journal of Obstetrics and Gynecology, 68, 1222-1242.

von Recklinghausen, F. (1896). Die Adenomyome und Cystadenome der Uterus und Tubenwandung: Ihre Abkunft von Resten des Wolff'schen Körpers. Hirschwald, Berlin.

Schiller, W. (1934). Zur Histogenese der Brennerscher Ovarialtumoren. Archiv für Gynäekologie, 157, 65-83.

Schiller, W. (1939). Mesonephroma ovarii. American Journal of Cancer, 35, 1-21.

Scully, R. E., and Barlow, J. F. (1967). 'Mesonephroma' of ovary: tumor of Müllerian nature related to the endometrioid carcinoma. Cancer, 20, 1405-1417.

Stange, H.-H. (1956). Ein Beitrag zur normalen und pathologischen Anatomie des Rete ovarii. Zentralblatt für Gynäkologie, 78, 81-85.

Sternberg, W. H. (1963). Nonfunctioning ovarian neoplasms. In The Ovary, edited by $\mathrm{H}$. G. Grady and D. E. Smith, pp. 209-254. Baillière, London; Williams and Wilkins, Baltimore.

Taxy, J. B., and Battifora, H. (1976). Female adnexal tumor of probable Wolffian origin: evidence for a low grade malignancy. Cancer, 37, 2349-2354.

Teilum, G. (1954). Histogenesis and classification of mesonephric tumors of the female and male genital system and relationship to benign so-called adenomatoid tumors (mesotheliomas). Acta Pathologica et Microbiologica Scandinavica, 34, 431-481.

Teilum, G. (1959). Endodermal sinus tumors of the ovary and testis: comparative morphogenesis of the so-called mesonephroma ovarii (Schiller) and extraembryonic (yolk sac-allantoic) structures of the rat's placenta. Cancer, 12, 1092-1105.

Wolfe, S. A. (1940). Gärtner's duct lesions of the cervix. American Journal of Obstetrics and Gynecology, 39, 312-322.

Requests for reprints to: Dr P. E. Hughesdon, Department of Morbid Anatomy, University College Hospital Medical School, University Street, London WC1E 6JJ, UK. 